\title{
Thermal hysteresis antifreeze agents in fishes from Spitsbergen waters
}

\author{
JOHN-PEDER DENSTAD, TORE AUNAAS, JAN FREDRIK BÖRSETH, ARNE VOLLAN AARSET AND
}

KARL ERIK ZACHARIASSEN

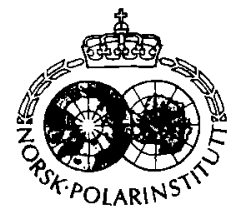
Denstad, J.-P., Aunaas, T., Börseth, J. F., Vollan Aarset, A. \& Zachariassen, K. E. 1987: Thermal
hysteresis antifreeze agents in fishes from Spitsbergen waters. Polar Research 5 n.s., 171-174.
The occurrence of macromolecular antifreeze agents (so-called Thermal Hysteresis Factors) in blood
plasma of fishes from Spitsbergen waters was investigated in August 1983, October 1984, and January 1986 .
Thermal hysteresis was found in the plasma of three species of Spitsbergen fishes: shorthorn sculpin
(Myoxocephalus scorpius), polar cod (Boreogadus saida), and sea snail (Liparis liparis). This is the first
time thermal hysteresis is reported from the sea snail. Seasonal changes in the amount of thermal hysteresis
were observed in blood plasma of the shorthorn sculpin and the sea snail.
With the exception of the polar cod, blood plasma of deep water fishes displays no thermal hysteresis.
The reason for this is probably that the polar cod also occurs in shallow ice laden sea water, where an
'antifreeze' would be needed to protect against inoculative freezing.
No thermal hysteresis was observed in blood plasma of the saithe (Pollachius virens), despite the fact
that the saithe was observed swimming in ice laden sea water at a temperature of -1 to $-1.5^{\circ} \mathrm{C}$ under
natural conditions, and was rapidly killed when it came into contact with ice in the laboratory. It is not
known how the saithe survives in ice laden water under natural conditions.

John-Peder Denstad, Tore Aunaas, Jan Fredrik Börseth, Arne Vollan Aarset and Karl Erik Zachariassen, Department of Zoology, AVH, University of Trondheim, 7055 Dragooll, Norway; November 1986 (revised August 1987).

Most species of teleost fish which inhabit temperate marine waters have blood plasma melting points (MPs) within the range -0.6 to $-0.8^{\circ} \mathrm{C}$ (Holmes \& Donaldson 1969). In the absence of ice, such fishes are capable to survive supercooling of -2 to $-3^{\circ} \mathrm{C}$. However, if ice is present, the supercooled fishes will immediately freeze and die due to inoculation of ice through the skin (Scholander et al. 1957). Polar oceans are characterized both by subzero water temperatures and the presence of ice. Since many marine fishes spend their entire life in these regions, they must possess specialized means of protecting themselves from freezing. Investigations have shown that many subpolar and polar fishes possess proteinaceous antifreeze agents, i.e. so-called thermal hysteresis factors (THF), (DeVries 1971; DeVries \& Lin 1977; Duman \& DeVries 1975). They act in a non-colligative way by causing a separation of melting point and freezing point (thermal hysteresis) of frozen samples of body fluid, so that ice crystals are prevented from growing upon cooling until a temperature lower than the melting point is reached. At this temperature, which is called the hysteresis freezing point (HFP), a rapid growth of ice crystals is observed.

This study presents information about the con- tent of THF in 16 species of fish from shallow and deep water at Spitsbergen.

\section{Material and methods}

\section{Sample collection}

The fishes were collected in the vicinity of $\mathrm{Ny}$ Ålesund, Spitsbergen, in August 1983, late October 1984, and in January 1986 . Shallow water fishes were collected by means of bow-nets and jigging at depths of 1-5 m. Deep water fishes were caught at a depth of $180 \mathrm{~m}$ from a trawler. Blood was collected from the caudal vein and artery by sucking it into glass capillary tubes by means of the capillary forces. After centrifugation on a Compur M 1100 micro centrifuge the plasma was sealed from air by a layer of paraffin oil, as described by Zachariassen et al. (1982), and frozen for later analysis.

\section{Determination of melting point and hysteresis freezing point}

The melting points and hysteresis freezing points of the blood plasma of the animals were deter- 
Table 1. The blood plasma hysteresis freezing points (HFP), melting points (MP), and amount of thermal hysteresis (MP-HFP) in several species of arctic fish at different seasons. Values are mean \pm SD. Numbers of specimens are given in parentheses.

\begin{tabular}{|c|c|c|c|c|c|c|}
\hline Date & Species & Family & $\begin{array}{l}\text { Fishing ground } \\
\text { depth (m) }\end{array}$ & $\begin{array}{l}\text { HFP } \\
\left({ }^{\circ} \mathrm{C}\right)\end{array}$ & $\begin{array}{l}\mathrm{MP} \\
\left({ }^{\circ} \mathrm{C}\right)\end{array}$ & $\begin{array}{l}\text { MP-HFP } \\
\left({ }^{\circ} \mathrm{C}\right)\end{array}$ \\
\hline \multirow{7}{*}{$\begin{array}{l}\text { August } \\
1983\end{array}$} & Myoxocephalus scorpius (1) & Cottidae & 3 & -1.36 & -0.78 & 0.58 \\
\hline & Gadus morhua (3) & Gadidae & 180 & $-0.90 \pm 0.14$ & $-0.90 \pm 0.14$ & 0 \\
\hline & Melanogrammus aeglefinus (2) & Gadidae & 180 & -0.93 & -0.93 & 0 \\
\hline & Boreogadus saida (3) & Gadidae & 180 & $-1.94 \pm 0.47$ & $-0.80 \pm 0.33$ & $1.14 \pm 0.59$ \\
\hline & Hippoglossoides platessoides (2) & Pleuronectidae & 180 & -0.78 & -0.78 & 0 \\
\hline & Sebastes marinus (3) & Scorpaenidae & 180 & $-0.95 \pm 0.08$ & $-0.95 \pm 0.08$ & 0 \\
\hline & Lycodes esmarki (1) & Lycodidae & 180 & -0.84 & -0.84 & 0 \\
\hline \multirow{7}{*}{1984} & Eumicrotremus spinosus (1) & Cyclopteridae & 180 & -0.79 & -0.79 & 0 \\
\hline & Mallotus villosus (1) & Osmeridae & 180 & -1.09 & -1.09 & 0 \\
\hline & Triglops pingeli (3) & Cottidae & 180 & $-0.92 \pm 0.30$ & $-0.92 \pm 0.30$ & 0 \\
\hline & Artediellus uncinatus (2) & Cottidae & 180 & -1.05 & -1.05 & 0 \\
\hline & Leptagonus decagonus (1) & Agonidae & 180 & -0.96 & -0.96 & 0 \\
\hline & Agonus cataphractus (1) & Agonidae & 180 & -1.20 & -1.20 & 0 \\
\hline & Boreogadus saida (1) & Gadidae & $1-3$ & -1.66 & -1.11 & 0.55 \\
\hline \multirow{3}{*}{$\begin{array}{l}\text { October } \\
1984\end{array}$} & Pollachius virens (1) & Gadidae & $1-3$ & -0.70 & -0.70 & 0 \\
\hline & Myoxocephalus scorpius (2) & Cottidae & $1-3$ & -1.81 & -0.76 & 1.05 \\
\hline & Liparis liparis (2) & Liparididae & $1-3$ & -1.34 & -0.73 & 0.61 \\
\hline January & Myoxocephalus scorpius (1) & Cottidae & $1-3$ & -1.71 & -0.77 & 0.93 \\
\hline \multirow[t]{2}{*}{1986} & Boreogadus saida (3) & Gadidae & $1-3$ & $-2.19 \pm 0.09$ & $-1.12 \pm 0.02$ & $1.06 \pm 0.08$ \\
\hline & Liparis liparis (4) & Liparididae & $1-3$ & $-1.90 \pm 0.11$ & $-0.92 \pm 0.08$ & $0.98 \pm 0.04$ \\
\hline
\end{tabular}

mined by using a Clifton nanolitre osmometer as described by Zachariassen \& Husby (1982a). The melting process of $30 \mathrm{nl}$ samples was observed in a microscope. while the temperature of the samples was regulated with an accuracy of $\pm 0.001^{\circ} \mathrm{C}$. The temperature at which the last tiny ice crystal disappeared during slow warming of the prefrozen sample was taken as the melting point. Plasma samples containing a tiny seeding ice crystal were then cooled. and the temperature at which a rapid growth of ice crystals took place was taken as the HFP (DeVries 1971).

\section{Survival of shallow' water fishes during contact with ice}

In an additional experiment a volume of 10 litres of seawater was cooled and partly frozen at a temperature of $-1.6^{\circ} \mathrm{C}$. Shallow water fishes of three different species were put in the ice laden sea water and their behaviour observed.

\section{Results}

The MPs, the HFPs, and the amount of thermal hysteresis in the blood plasma of fishes from Spitsbergen are shown in Table 1. The data reveal that all deep water species investigated in the autumn had blood plasma MPs in the range of -1.09 to $-0.78^{\circ} \mathrm{C}$. All shallow water fishes investigated in the summer, autumn, and winter had MPs in the range of -1.12 to $-0.70^{\circ} \mathrm{C}$.

In most of the species caught at deep water, the HFP of the blood plasma corresponds to the MP, indicating that THFs were absent from their plasma. However, the blood plasma of polar cod (Boreogadus saida) showed a hysteresis of about $1.1^{\circ} \mathrm{C}$, revealing the presence of THF in the blood plasma of this species.

Plasma from the arctic shorthorn sculpin (Myoxocephalus scorpius), collected in shallow water in August 1983, had an MP of $-0.78^{\circ} \mathrm{C}$, and a hysteresis $\left(0.58^{\circ} \mathrm{C}\right)$ was present (Table 1).

Blood plasma of polar cod, arctic shorthorn sculpin, and sea snail (Liparis liparis) collected in shallow water in late October showed a thermal hysteresis of $0.55,1.05$, and $0.61^{\circ} \mathrm{C}$, respectively, indicating that THFs are present in the blood plasma of these species. The hysteresis effect in the blood plasma of $M$. scorpius was significantly 
Table 2. Survival time of three species of Arctic fish in ice laden sea water in October. Values are mean \pm SD. Number of specimens are given in parentheses.

\begin{tabular}{lll}
\hline Species & $\begin{array}{l}\text { Water } \\
\text { temperature } \\
\left({ }^{\circ} \mathrm{C}\right)\end{array}$ & $\begin{array}{l}\text { Survival } \\
\text { time } \\
(\mathrm{min})\end{array}$ \\
\hline Pollachius virens (2) & -1.6 & 0 \\
Myoxocephalus scorpius (1) & ice & 63 \\
Boreogadus saida (2) & present & 30 \\
\hline
\end{tabular}

greater in specimens collected in October than in those collected in August. In saithe (Pollachius virens), collected in shallow water in late October, the HFP corresponded to the MP, indicating that THFs are absent from the blood plasma.

The MP and the HFP in the blood plasma of sea snail collected in shallow water were substantially lower in animals collected in January than in animals collected in October, and the thermal hysteresis effect was stronger in January than in October (Table 1).

The HFP in the blood plasma of polar cod collected in shallow water was lower in January than in October. The hysteresis effect was also stronger in January than in October (Table 1).

On the contrary, for the shorthorn sculpin there were no differences in any of the parameters from October to January (Table 1).

The survival times of the fish exposed in ice laden sea water in late October are shown in Table 2. Sea water was supercooled and then seeded with a few ice crystals. The sea water was then immediately filled up with a whole flurry of ice crystals. The temperature was $-1.6^{\circ} \mathrm{C}$. One individual of saithe froze and died immediately when put into the ice laden sea water, whereas polar cod and arctic shorthorn sculpin survived for $\frac{1}{2}$ hour and 1 hour, respectively.

\section{Discussion}

Eleven out of twelve deep water fish species from Spitsbergen showed no thermal hysteresis in their blood plasma in the autumn (Table 1). These fishes could survive the winter in a supercooled state since they would not come into contact with seeding ice (Scholander et al. 1957). However, plasma from polar cod caught at deep water showed hysteresis. The reason for this may be that the polar cod is also found in shallow ice laden water, where an 'antifreeze' effect would be needed to protect against inoculative freezing. The presence of THFs has been reported in some deep water fish species also in previous studies (Duman \& DeVries 1975).

The present observation of THFs in the blood plasma of sea snail (L. liparis) is the first observation of such antifreeze agents in this species. Blood plasma of sea snail, collected in shallow water, also showed a seasonal change in the THF from $-1.34^{\circ} \mathrm{C}$ in October to $-1.90^{\circ} \mathrm{C}$ in January (Table 1). In the same period the MP of the blood plasma was lowered by about $0.2^{\circ} \mathrm{C}$. Thus, thermal hysteresis effect in the blood plasma of the sea snail increased by about $60 \%$ from October to January. This probably reflects a better protection against both the lower water temperatures prevailing in the winter and the presence of more ice.

Blood plasma of shorthorn sculpin, collected in shallow water, displayed thermal hysteresis in the summer, autumn, and winter (Table 1). The maintenance of plasma antifreeze proteins throughout the year appears to be a feature common to a number of fish species residing in polar and sub-polar oceans (Fletcher et al. 1982). During the summer months the Alaskan sculpin (Myoxocephalus verrucosus) loses $50 \%$ of its winter levels of antifreeze, probably reflecting the higher water temperature of $7^{\circ} \mathrm{C}$ at this time (DeVries 1980). In the blood plasma of shorthorn sculpins from Spitsbergen the thermal hysteresis effect increased by about $60-80 \%$ from August to October.

Individuals of saithe were collected in shallow water containing ice. No thermal hysteresis was observed in the blood plasma of this species (Table 1). Previous studies have shown that some bottom living fish species from shallow frozen bays in Nova Scotia do not have a thermal hysteresis effect in their blood plasma. These fish probably survive simply by avoiding contact with the surface ice (Duman \& DeVries, 1975).

Fish species with no 'antifreeze' in their blood plasma are capable of surviving supercooling of -2 to $-3^{\circ} \mathrm{C}$ in the absence of ice. However, if ice is present, ice crystals appear to penetrate the outer epithelium and cause the supercooled fish to freeze and die immediately (Scholander et al. 1957). The present experiments at Spitsbergen show that the saithe died immediately when put in ice laden sea water at a temperature of $-1.6^{\circ} \mathrm{C}$ (Table 2), whereas the polar cod and the short- 
horn sculpin survived for about $\frac{1}{2}$ and 1 hour, respectively. This is in good agreement with the fact that THFs are lacking in the blood plasma of the saithe and that THFs are present in the blood plasma of the polar cod and the shorthorn sculpin. These observations support the view that THFs are important to prevent inoculative freezing, in the same way that previous work has shown that THFs play an important role in hibernating freeze-sensitive insects (Zachariassen \& Husby 1982b).

Acknowledgements. - This study was made possible by cconomic support from the Norwegian Polar Research Institute, the Norwegian Rescarch programme for Marine Arctic Ecology (PRO MARE), the oil company FINA, and the Department of Zoology. University of Trondheim. We also want to thank the crew onboard the trawler 'Nordstjernen' from the Faroe Islands. who provided us with deep water fishes.

\section{References}

DeVries. A. L. 1971: Glycoproteins as biological antifreeze agents in antarctic fishes. Science, N.Y. 172, 1152-1155.

DeVries. A. L. 1980: Biological antifreezes and survival in freczing environments. Pp. 583-607 in Gilles. R. (ed.): Ani- mals and Environmental Fitness 1. Pergamon Press, Toronto. DeVries, A. L. \& Lin, Y. 1977: The role of glycoprotein antifreezes in the survival of Antarctic fishes. Pp. 439-458 in Llano, G. A. (ed.): Adaptations within antarctic ecosystems. Proceedings of the third SCAR symposium on Antarctic Biology. Gulf Publishing Co., Houston.

Duman, J. G. \& DeVries, A. L. 1975: The role of macromolecular antifreezes in cold water fishes. Comp. Biochem. Physiol. 52A, 193-199.

Fletcher, G. L., Addison, R. F., Slaughter, D. \& Hew, C. L. 1982: Antifreeze proteins in the arctic Shorthorn Sculpin (Myoxocephalus scorpius). Arctic. 35 (2), 302-306.

Holmes, W. N. \& Donaldson, E. M. 1969: The body compartments and distribution of electrolytes. Pp. 1-89 in Hoar, W. S. \& Randall. D. S. (eds.): Fish physiology J. Academic Press, New York.

Scholander, P. F., van Dam, L., Kanwisher, J. W., Hammel, H. T. \& Gordon. M. S. 1957: Supercooling and osmoregulation in Arctic fish. J. Cell. Comp. Physiol. 49, 5-24.

Zachariassen, K. E., Baust, J. G. \& Lee, R. E. Jr. 1982: A Method for Quantitative Determination of Ice Nucleating Agents in Insect Hemolymph. Cryobiology 19, 180-184.

Zachariassen, K. E. \& Husby, J. A. 1982a: Antifrecze effect of thermal hysteresis agents protects highly supercooled insects. Nature 298, 865-867.

Zachariassen, K. E. \& Husby, J. A. 1982b: Stabilization of highly supercooled insects by thermal hysteresis agents. (Abstract from Symposium on Invertebrate Cold-Hardiness, Oslo 1982.) Cryo-Letters 3, 316. 